\title{
Cryostat section assay of oestrogen and progesterone receptors in meningiomas: a clinicopathological study
}

\author{
JW IRONSIDE, * RDE BATTERSBY, $\dagger$ VICTORIA JM DANGERFIELD, \\ MA PARSONS, $\ddagger$ WR TIMPERLEY,* JCE UNDERWOOD $\ddagger$
}

From the *Departments of Neuropathology and $†$ Neurosurgery, Royal Hallamshire Hospital, Sheffield, and the $\ddagger$ Department of Pathology, University of Sheffield Medical School, Sheffield

SUMMARY Oestrogen receptors and progesterone receptors were measured in the cytosols from cryostat sections of 45 meningiomas from 40 patients (12 men, 28 women) using an isoelectric focusing technique. Near fascimile adjacent sections from the same tissue blocks were stained and examined to determine the histological subtype of the neoplasms. Appreciable levels of progesterone receptor ( $>10 \mathrm{fmol} / \mathrm{mg}$ cytosol protein) were present in $24(53.3 \%)$ of the neoplasms, but no clinically important oestrogen receptor was detected in any of the tumours. Competitive binding studies on control tissues confirmed the specificity of the assay procedures. No correlation was found between progesterone receptor state and the age, sex, or menopausal state of the patients, or the histological subtype and site of the neoplasms. Four of the patients studied had multiple intracranial neoplasms, which in two were of differing progesterone receptor state. The presence of specific progesterone receptor in meningioma cytosols raises the possibility of hormonal manipulation in the treatment of this group of neoplasms.

Meningiomas account for $13-18 \%$ of intracranial neoplasms and $25 \%$ of intraspinal neoplasms. ${ }^{1}$ Two thirds of meningiomas occur in women, ${ }^{1}$ and for many years it has been known that meningiomas in women may enlarge and become symptomatic during periods of hormonal flux, ${ }^{2}$ particularly during pregnancy ${ }^{3}$ and in the luteal phase of the menstrual cycle. ${ }^{4}$ An increased incidence of meningiomas occurs in women with breast carcinoma, ${ }^{5}$ a neoplasm that often contains oestrogen receptors and progesterone receptors and which exhibits hormonally dependent growth. ${ }^{6}$ Oestrogen receptor and progesterone receptor have recently been found in normal leptomeninges, ${ }^{7}$ the tissue from which meningiomas are thought to arise in man.

These observations have prompted several investigations into the presence of oestrogen receptor and progesterone receptor in meningiomas, ${ }^{8-26}$ and it has been postulated that the presence of such receptors might be of prognostic and therapeutic value, as for breast carcinoma. All of the assays performed to date have measured oestrogen receptor and progesterone receptor in the cytosol fractions from tissue homogenates of meningiomas. A wide range of results has been obtained, and although an associ-

Accepted for publication 21 August 1985

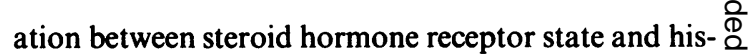
tological subtype of meningioma has been $\overrightarrow{\vec{O}}$ claimed, ${ }^{1920}$ this observation has not been consis- $\frac{\partial}{3}$ tent. $^{2123}$ Histological typing of meningiomas is usually performed on an adjacent portion of tumour to the sample taken for homogenisation and steroid receptor assay. These two portions of tissue, however, may not be exact replicates as meningiomas are heterogenous neoplasms which may exhibit considerable histological variability. ${ }^{1}$

We overcame this problem by assaying oestrogen receptor and progesterone receptor in the diffusate of cryostat sections of meningiomas, thus allowing $\triangle$ simultaneous histological analysis and steriod hormone receptor assay on adjacent near facsimile sam- $N$ ples. This method is based on the observation that unoccupied oestrogen receptor and progesterone $N$ receptor readily diffuse from unfixed cryostat sections $\omega$ immersed in an aqueous medium without the need for mechanical homogenisation. ${ }^{27-29}$

\section{Material and methods}

Forty five consecutive meningiomas were studied $\frac{0}{\frac{0}{0}}$ from 40 patients ( 28 women, 12 men) of mean age $\frac{\rho}{\odot}$ 55.5 years (age range 33-79). Four patients (three $\stackrel{\odot}{\varnothing}$ women, one man) had multiple tumours; of these, one 
woman came from a family with neurofibromatosis with predominantly central affliction. The site of origin of each neoplasm was identified radiologically and confirmed at the time of surgery.

\section{TISSUE COLLECTION AND STORAGE}

Fresh tissue obtained during surgery was trimmed into blocks measuring about $10 \times 10 \times 5 \mathrm{~mm}$ suitable for cryostat microtomy. These were snap frozen and stored at $-70^{\circ} \mathrm{C}$. Fresh uterus for positive control tissue was obtained from oophorectomised rats for oestrogen receptor assay and from rats killed one week after subcutaneous implantation of a pellet containing $12 \mathrm{mg}$ hexoestrol (Boots Company Limited) for progesterone receptor assay. The control tissues were frozen and stored under identical conditions to the meningiomas.

\section{CRYOSTAT SECTIONS AND RECEPTOR ASSAY}

Cryostat sections for receptor assay were cut at $40 \mu \mathrm{m}$, and two additional sections from each block for histology were then cut from the same tissue surface at $6 \mu \mathrm{m}$ with minimal trimming. Both sections were stained by haematoxylin and eosin to permit classification of the histological subtype of each tumour. This was performed without knowledge of the receptor assay results.

Oestrogen receptor assay was performed on cytosols from the cryostat sections with incubation on ice for one hour with ${ }^{3} \mathrm{H}$-oestradiol followed by trypsinisation as previously described in a method for breast carcinomas. ${ }^{30}$ For progesterone receptor assay duplicate sets of cryostat sections $(40 \mu \mathrm{m})$ to give a total section area greater than $1 \mathrm{~cm}^{2}$ were collected on small glass coverslips and dropped into $70 \times 9 \mathrm{~mm}$ plastic tubes containing $200 \mu \mathrm{l}$ progesterone receptor buffer ( $5 \mathrm{mM} \mathrm{KH}_{2} \mathrm{PO}_{4}, 2 \mathrm{mM}$ mercaptoethanol, $10 \%$ $\mathrm{W} / \mathrm{V}$ glycercol, $0.05 \% \mathrm{~W} / \mathrm{V}$ bovine serum albumin, $\left.0.02 \% \mathrm{~W} / \mathrm{V} \mathrm{NaN} \mathrm{Na}_{3} ; \mathrm{pH} 7.4\right)$. The glass coverslips were then crushed gently, and a further $200 \mu$ l of progesterone receptor buffer containing $2 \times 10^{-9} \mathrm{M}$ ${ }^{3}$ H-ORG2058 (58 Ci/mM; Amersham International) was added immediately. The tubes were kept on ice for two hours during which they were gently agitated at 15-20 minute intervals. The tubes were then centrifuged at $2500 \mathrm{rpm}$ for 10 minutes at $4^{\circ} \mathrm{C}$. Supernatant enriched with cytosol $(300 \mu \mathrm{l})$ was gently aspirated and added to a clean plastic tube containing $150 \mu \mathrm{l}$ of dextran coated charcoal $(1.0 \mathrm{~g}$ activated charcoal, $0.1 \mathrm{~g}$ dextran $\mathrm{T}-500,100 \mathrm{ml}$ progesterone receptor buffer). The mixture was agitated, incubated for five minutes on ice, and then centrifuged at $2500 \mathrm{rpm}$ for 10 minutes at $4^{\circ} \mathrm{C}$. Supernatant $(50 \mu \mathrm{l})$ was aspirated, and the protein concentration measured by a modified Lowry method ${ }^{31}$ against a blank containing $50 \mu \mathrm{l}$ progesterone receptor buffer alone. Two $\times$ $100 \mu \mathrm{l}$ aliquots of the remaining supernatant were then subjected to isoelectric focusing.

\section{DIFFUSION AND BINDING STUDIES}

To estimate the rate of diffusion of receptor protein from cryostat sections progesterone receptor concentrations were measured in sections of control tissue (rat uterus) after immersion in buffer for two minutes, 15 minutes, 30 minutes, one hour, and two hours, before the addition of ${ }^{3} \mathrm{H}-\mathrm{ORG} 2058$, as described above. To estimate the optimum incubation period for ligand-receptor binding after the addition of ${ }^{3} \mathrm{H}-\mathrm{ORG} 2058$ cryostat sections of control tissue were incubated with the radioligand for five minutes, 15 minutes, 30 minutes, one hour, two hours, and three hours. The progesterone receptor concentration in the supernatant was then determined.

\section{COMPETITIVE BINDING STUDIES}

To investigate the specificity of binding of ORG2058 to cytosolic progesterone receptor incubations of section cytosols with $2 \times 10^{-9} \mathrm{M}^{3} \mathrm{H}-\mathrm{ORG} 2058$ were conducted either alone or in the presence of a 100 fold molar excess of either progesterone (Sigma), diethylstilboestrol (Sigma), hydrocortisone (Sigma), or testosterone (Sigma). Incubations were also performed with dexamethasone (Decadron; Merck, Sharp and Dohme) at concentrations of $2 \times 10^{-9} \mathrm{M}$ and 10,100 and 1000 fold molar excess. After incubation for two hours on ice the assay tubes were centrifuged, and the amount of receptor bound ${ }^{3} \mathrm{H}-\mathrm{ORG} 2058$ measured.

\section{ISOELECTRIC FOCUSING}

Isoelectric focusing was performed on duplicate $100 \mu \mathrm{l}$ aliquots of cytosol supernatant after incubation with ${ }^{3} \mathrm{H}-\mathrm{ORG} 2058$ and dextran coated charcoal. Each sample was pipetted into a plastic application frame $(10 \times 6 \times 2 \mathrm{~mm})$ placed $10 \mathrm{~mm}$ from the cathodal electrode strip on the surface of a thin layer polyacrylamide gel $(245 \times 110 \times 1 \mathrm{~mm} ; 2.4 \% \mathrm{~W} / \mathrm{V}$ ampholine, $\mathrm{pH} 3 \cdot 5-9 \cdot 5$; LKB). The focusing conditions were similar to those used by Underwood $e t$ $a l^{30}$ After focusing for 90 minutes the gel along each sample track was cut into $5 \mathrm{~mm}$ slices, each of which was placed into a scintillation phial, to which was added $4 \mathrm{ml}$ of $\mathrm{HP} / \mathrm{b}$ scintillant (Beckman). The phials were then incubated in a water bath at $50^{\circ} \mathrm{C}$ for one hour with gentle agitation.

\section{CALCULATION OF RECEPTOR CONCENTRATION}

The radioactivity of each phial was measured by liquid scintillation, counting with quench monitoring by $H$ number (external standard Compton Edge monitoring using ${ }^{137} \mathrm{Cs}$ ). Counting was performed in an LS1801 automated liquid scintillation spectrometer (Beckman). A histogram of radioactivity against gel slice number was plotted for each sample and the cumulative height of the points in the single peak, typically located about $5 \mathrm{~cm}$ from the cathodal electrode strip ( $\mathrm{pH}$ 6.2), was measured above the dia- 


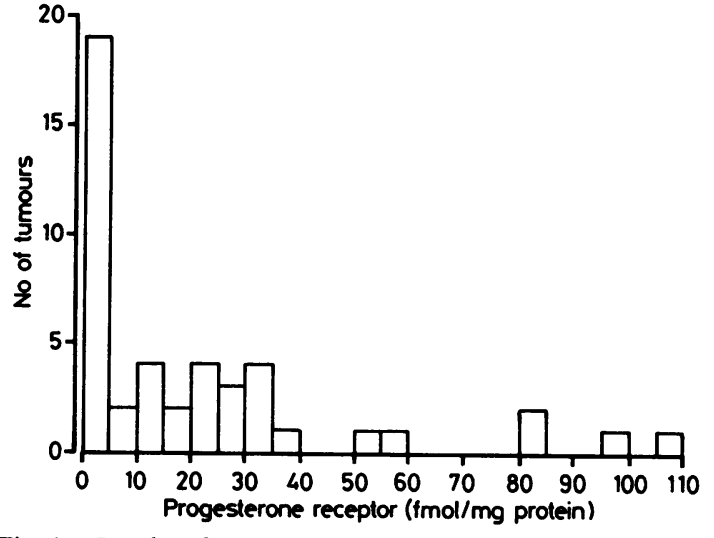

Fig. 1 Results of progesterone receptor assay. Nineteen neoplasms contained no detectable cytosolic progesterone receptor, while two neoplasms contained concentration of less than $10 \mathrm{fmol} / \mathrm{mg}$ cytosol protein.

grammatic baseline. The amount of ${ }^{3} \mathrm{H}-\mathrm{ORG} 2058$ within the peak was calculated by computer, and the results were finally expressed in $\mathrm{fmol} / \mathrm{mg}$ of cytosol protein. If the results for the duplicate assays from each tissue sample varied by more than $10 \%$ the assay was repeated.

\section{SCATCHARD PLOT ANALYSIS}

A measurement of the affinity of ${ }^{3} \mathrm{H}-\mathrm{ORG} 2058$ for cytosolic progesterone receptor was performed. Cryostat section cytosol in progesterone receptor buffer $(100 \mu \mathrm{l})$ was added to either $50 \mu \mathrm{l}$ of unlabelled ORG2058 at a concentration of $150 \mathrm{nmol} / 1$ to esti-

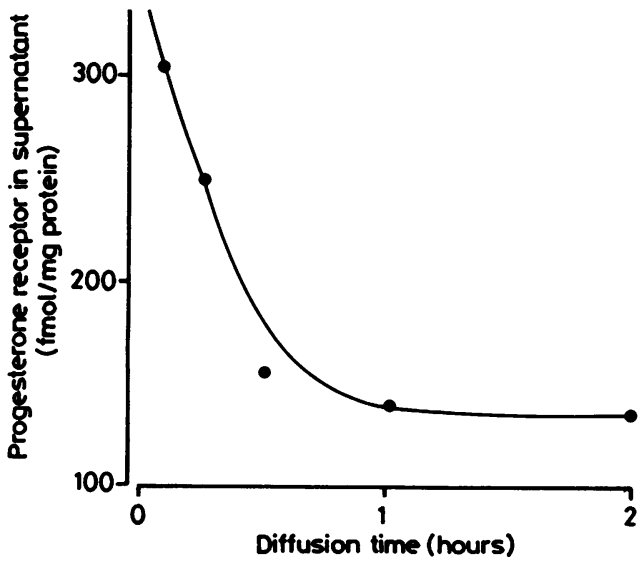

Fig. 2 Diffusion study shows rapid diffusion of progesterone receptor from cryostat section into aqueous buffer in the first few minutes after immersion. Progesterone receptor is labile and decays following prolonged immersion before ${ }^{3} \mathrm{H}-\mathrm{ORG} 2058$ is added. After each interval a two hour incubation with radioligand was performed and cytosolic progesterone receptor measured by isoelectric focusing.

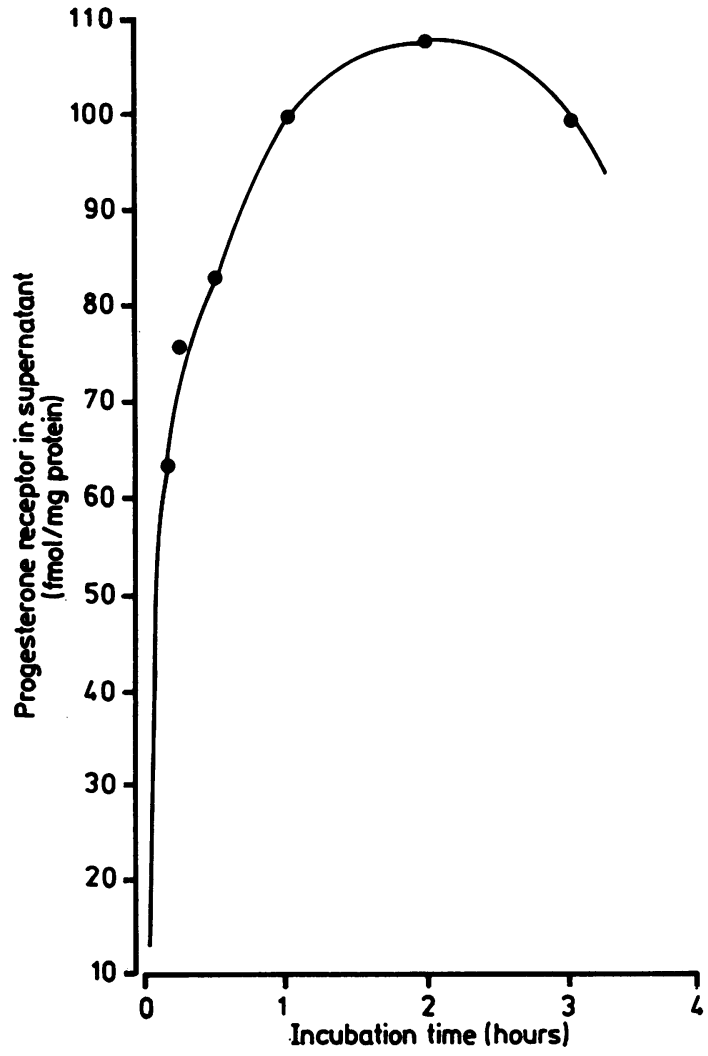

Fig. 3 Progesterone receptor binding study shows that optimal concentrations of progesterone receptor/radioligand complexes were detected by isoelectric focusing after a two hour incubation of cytosol with $2 \times 10^{-9} M^{3} \mathrm{H}-O R G 2058$ following immersion of cryostat section in buffer for two minutes.

mate non-specific binding, or $50 \mu$ l of progesterone receptor buffer to measure the total binding of the radiolabelled ligand. The mixtures were incubated for 30 minutes on ice, then $100 \mu$ l of ${ }^{3} \mathrm{H}-\mathrm{ORG} 2058$ at concentrations varying from $400-10000 \mathrm{fmol} / \mathrm{ml}$ was added. For each concentration of radioligand a blank specimen containing $100 \mu \mathrm{l}$ of radioligand and $150 \mu \mathrm{l}$ of progesterone receptor buffer, but no cytosol or unlabelled ORG2058, was prepared. Background counts were measured from specimens containing $250 \mu \mathrm{l}$ of progesterone receptor buffer only. All of the above were incubated overnight at $4^{\circ} \mathrm{C}$. Dextran coated charcoal (prepared as above) $(200 \mu \mathrm{l})$ was then added followed by incubation on ice for 30 minutes. After centrifugation at $2000 \mathrm{rpm}$ for 10 minutes at $4^{\circ} \mathrm{C}, 50 \mu \mathrm{l}$ of the supernatant was removed for protein estimation. The concentration of bound radioligand in $\mathrm{fmol} / \mathrm{ml}$ in the reaction was calculated and plotted against the bound/free ratio for each of the concentrations used. ${ }^{32}$ 


\section{Results}

\section{STEROID HORMONE RECEPTORS}

Fig. 1 shows the results of progesterone receptor assays. Of the 45 neoplasms examined, $24(53.3 \%)$ were positive for progesterone receptor $(>10 \mathrm{fmol} / \mathrm{mg}$ cytosol protein). Only one of the neoplasms contained detectable oestrogen receptor at a concentration of $2.3 \mathrm{fmol} / \mathrm{mg}$ cytosol protein; this result is not important-that is, $(<10 \mathrm{fmol} / \mathrm{mg}$ cytosol protein). Of the group of patients with multiple meningiomas, two women had neoplasms both positive and negative for progesterone receptor while one woman had two negative neoplasms for progesterone receptor and the man had two neoplasms positive for progesterone receptor.

\section{DIFFUSION AND BINDING STUDIES}

Fig. 2 shows the results of the diffusion study for progesterone receptor. Rapid diffusion of cytosolic receptor into the aqueous medium necessitates the addition of radiolabelled ligand for progesterone receptor assay as soon as possible after placing the cryostat sections into the buffer and crushing the glass coverslip. Fig. 3 shows the results of the binding study for ${ }^{3} \mathrm{H}-\mathrm{ORG} 2058$ and progesterone receptor. An incubation period of two hours was deemed to give the most satisfactory results with this ligand and reflected similar experiences by other workers. ${ }^{33}$

\section{COMPETITIVE BINDING}

Fig. 4 shows the results of the competitive binding experiment. No important level of competitive binding was found with any of the steroid hormones other than progesterone; in particular, no competitive binding with dexamethasone was found at any of the concentrations used.

\section{SCATCHARD PLOT ANALYSIS}

Fig. 5 shows the graph obtained from the results of a Scatchard plot analysis. The calculated $\mathrm{kD}$ for the reaction is $0.704 \mathrm{nmol} / 1$, indicating a high affinity reaction between the radioligand and the cytosolic progesterone receptor.

\section{TISSUE STORAGE}

No important difference between the results of receptor assays repeated on tissues stored for up to six months was found, indicating the stability of cytosolic progesterone receptor at the conditions of storage specified above.

\section{HISTOLOGY}

Table 1 shows the histological subtypes ${ }^{34}$ of the neo: plasms studied listed in relation to progesterone receptor state. Although the numbers are too smal to permit statistical analysis, interestingly, the ana-

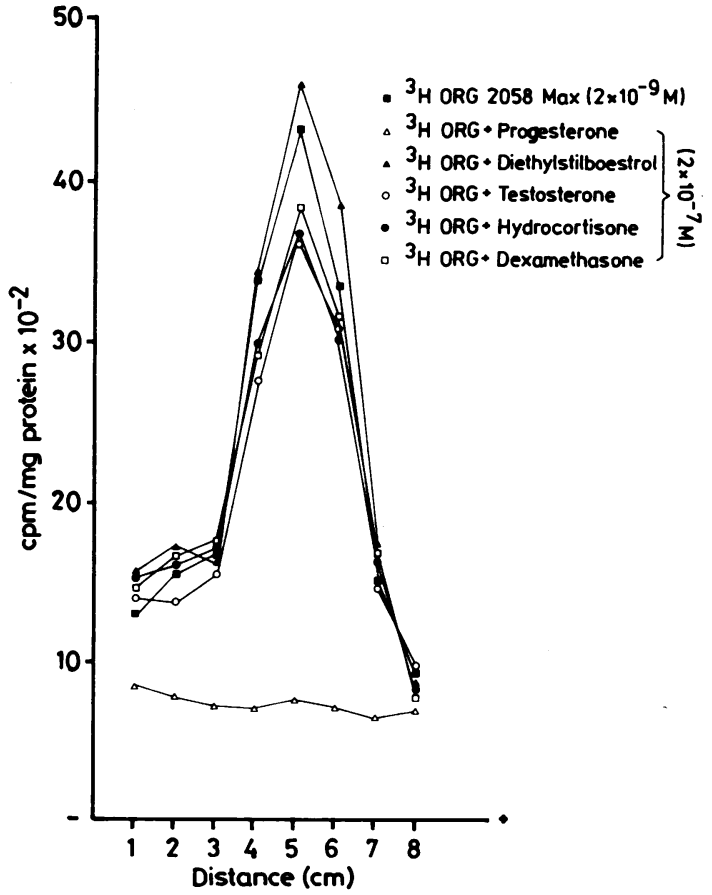

Fig. 4 Specificity of ${ }^{3} \mathrm{H}$-ORG2058 for progesterone receptor is shown by competitive binding study where suppression of isoelectric focusing peak for progesterone receptor/radioligand complexes occurs only in presence of excess unlabelled progesterone. Incubations were performed with $2 \times 10^{-9} \mathrm{M}^{3} \mathrm{H}$-ORG2058 alone ( $\mathrm{O}$ ) and in the presence of progesterone $(\triangle)$, diethylstilboestrol $(\mathbf{\Delta})$, testosterone ( $\mathrm{O})$, hydrocortisone (O), and dexamethasone ( $\square)$, each in 100 fold molar excess $\left(2 \times 10^{-7} \mathrm{M}\right)$.

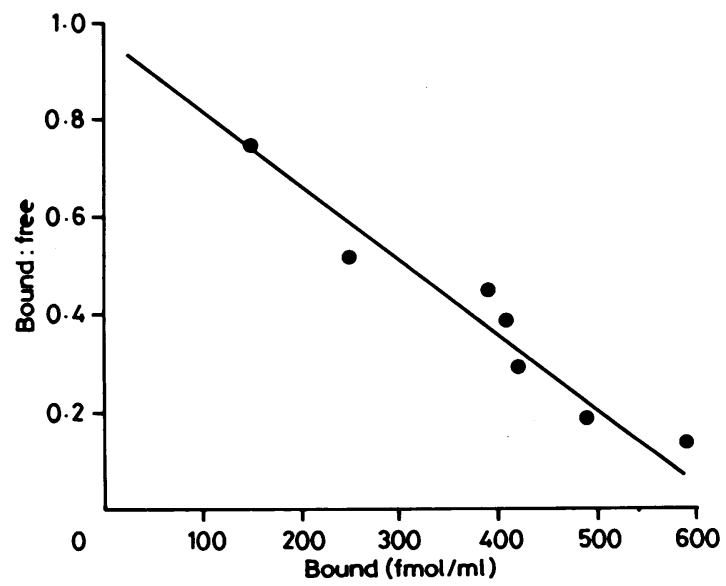

Fig. 5 Scatchard analysis of progesterone receptor $/{ }^{3} \mathrm{H}-\mathrm{ORG} 2058$ binding in meningioma cytosol shows a straight line plot of regression 0.922 , giving $a k D$ of $0.704 \mathrm{nmol} / \mathrm{l}$. 
Table 1 Histological subtype in relation to progesterone receptor state

\begin{tabular}{lll}
\hline $\begin{array}{l}\text { Subtype (WHO) } \\
\text { Positive for } \\
\text { progesterone } \\
\text { receptor }\end{array}$ & $\begin{array}{l}\text { Negative for } \\
\text { progesterone } \\
\text { receptor }\end{array}$ \\
\hline Transitional & 10 & 8 \\
Meningotheliomatous & 8 & 5 \\
Fibrous & 2 & 3 \\
Psammomatous & 3 & 0 \\
Angiomatous & 0 & 2 \\
Anaplastic & 0 & 2 \\
Haemangioblastic & 0 & 1 \\
Microcystic & 1 & 0 \\
\hline
\end{tabular}

Table 2 Site of neoplasm in relation to progesterone receptor state

\begin{tabular}{lll}
\hline Site & $\begin{array}{l}\text { Positive for } \\
\text { progesterone } \\
\text { receptor }\end{array}$ & $\begin{array}{l}\text { Negative for } \\
\text { progesterone } \\
\text { receptor }\end{array}$ \\
\hline Convexity & 8 & 10 \\
Central basal & 6 & 1 \\
Parasagittal & 3 & 6 \\
Lateral basal & 4 & 2 \\
Intraventricular & 0 & 2 \\
Spinal & 3 & 0 \\
\hline
\end{tabular}

plastic, angiomatous, and haemangioblastic neoplasms were all negative for progesterone receptor, whereas all the psammomatous neoplasms were positive for progesterone receptor. No significant differences in progesterone receptor state between the larger groups of transitional and meningotheliomatous neoplasms was found $\left(\mathrm{p}>0.05, \chi^{2}\right.$ test).

\section{CLINICAL FEATURES}

No significant difference was found between the age distributions of the groups of patients with neoplasms positive or negative for progesterone receptor $(p>$ $0.05, \chi^{2}$ test). Among the women there was no correlation between menopausal state and the presence of progesterone receptors in the neoplasm ( $p>0.05$, $\chi^{2}$ test). No significant difference was found between the sex distribution in the groups of patients with neoplasms positive or negative for progesterone receptor ( $p>0.05, \chi^{2}$ test). Table 2 lists the sites of the neoplasms examined in relation to progesterone receptor state. No significant association was found between progesterone receptor state and neoplasms occurring in midline, lateral, or basal sites ( $p>0.05, \chi^{2}$ test).

\section{Discussion}

The technique for steroid hormone receptor assay described in this study has an important advantage over previous methods entailing tissue homogenisation in that it facilitates accurate histological classification of an adjacent near facsimile section to the assayed sample. This is of particular importance in meningiomas, which are often heterogenous in $\stackrel{0}{\overrightarrow{5}}$

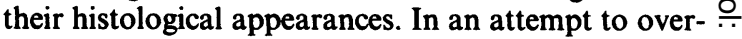
come this problem when dealing with tissue homoge- $\overrightarrow{\vec{F}}$ nates some authors have classified meningiomas into typical or atypical histological subtypes. ${ }^{25}$ The criteria used in the recognition of these groups, however, $\frac{\bar{\sigma}}{\bar{D}}$ leave a considerable overlap between the more clearly $\frac{\sigma}{\sigma}$ defined histological subtypes and do not differentiate $\propto$ between locally infiltrative benign or anaplastic neo- $\approx$ plasms. Other authors have claimed that tissue $\overrightarrow{0}$ homogenates of presumed meningoendotheliomatous meningiomas contain more progesterone receptor $\vec{\omega}$ than transitional or fibroblastic tumours, ${ }^{19}$ but no $\frac{\rho}{2}$ evidence to support this claim was found in the ? present study. From our results it seems that there is no relation between the histological subtype of the neoplasm and the steroid hormone receptor state, $\stackrel{f}{A}$ although it will be necessary to examine more cases of 을 the rarer subtypes to fully assess this relation.

The presence of steroid hormone receptors in meningiomas was first investigated in 1979 by Donnell et al who reported the presence of oestrogen receptor in four out of six meningiomas. ${ }^{8}$ Since then many studies have been published on the presence of $\overrightarrow{0}$ oestrogen receptor and progesterone receptor in tis- ? sue homogenates from meningiomas. ${ }^{9-26}$ There is considerable disparity between the published results, some authors claiming to have found an appreciable number of neoplasms that were positive for oestrogen receptor, ${ }^{8-1012141617202326}$ while others have found that most meningiomas were negative for oestrogen receptor. ${ }^{1113151819212225}$ There does appear to be general agreement that progesterone receptor is present in meningiomas, although the incidence of positive neoplasms varies considerably from series to series. A recent review by Cahill et al found that the ? results of analysis of steroid hormone receptor in $\overline{0}$ meningiomas fell into two main groups, depending on the presence of clinically important oestrogen receptor. ${ }^{21}$ Interestingly, most of the reports describing high concentrations of oestrogen receptor binding in a large proportion of neoplasms originate from France. ${ }^{9122023}$ Various theories have been put forward to explain this. ${ }^{2123}$ These include differences in the techniques of tissue biopsy, freezing, duration of $O$ storage, and methods of homogenisation. These vari- $\tilde{O}$ ables, however, have differed in other reports, which స్ట are unanimous in finding low or undetectable concentrations of oestrogen receptor. Another explanation for this discrepancy is the effect of preoperative treatment with dexamethasone on oestrogen receptor and $\stackrel{\infty}{\longrightarrow}$ progesterone receptor in meningiomas. ${ }^{12}$ Poisson et 0 al reported high concentrations of oestrogen receptor in tumours from patients who had been treated preoperatively with glucocorticoids. ${ }^{23}$ These findings contrast with those from an earlier series from the same laboratory ${ }^{12}$ and with a series from Sweden, ${ }^{14}$ 
same laboratory ${ }^{12}$ and with a series from Sweden, ${ }^{14}$ in which pretreatment with dexamethasone apparently resulted in considerably lower concentrations of progesterone receptor. All the patients in the present report had received preoperative or intraoperative dexamethasone, and so we were unable to perform a similar comparison. The results of the competitive binding experiment, however, indicate that dexamethasone does not interfere with the progesterone receptor or oestrogen receptor assays used in our experiments.

It has also been suggested that differences in the radiolabelled ligands used in the various reported series might account for the differing results. ${ }^{21}$ Most of the assays to detect oestrogen receptor have been performed using ${ }^{3} \mathrm{H}$-oestradiol, although R2858 (11-beta-methoxy-17-beta-ethynylestradiol) was used as the oestrogen analogue by workers in France. 91220 It has been suggested that this ligand might offer a more accurate oestrogen receptor assay as it does not bind to human sex hormone binding globulin in the serum, and that binding to such serum proteins may lead to artefactually high results if ${ }^{3} \mathrm{H}$-oestradiol is used. ${ }^{35}$ Surprisingly, the incidence of oestrogen receptor in meningiomas when measured using R2858 is much higher than when ${ }^{3} \mathrm{H}$-oestradiol has been used. All the previous reports used the synthetic analogue R5020 ( ${ }^{3} \mathrm{H}$-promegesterone) as the progesterone analogue in the progesterone receptor assay. ${ }^{8-26}$ The analogue used in this study ${ }^{3} \mathrm{H}-\mathrm{ORG} 2058$ (16 alphaethyl-21-hydroxy-19-nor-[6,7- $\left.{ }^{3} \mathrm{H}\right]$ preg-4-en-3,20 dione) was chosen because of its specific high affinity binding to progesterone receptor, resulting in a stable complex ${ }^{3637}$ with low cross reactivity with other cytosol receptor sites and with serum corticosteroid binding globulin. ${ }^{37}{ }^{3} \mathrm{H}-\mathrm{ORG} 2058$ exhibits lower nonspecific binding than R5020, which may bind weakly to cytosolic glucocorticoid receptors. ${ }^{38}$ The results of the progesterone receptor assay in this report were broadly similar to those of several previous reports 11181925 although direct comparisons are difficult because of differences in assay technique, measurement of receptors, and interpretation of a significant result.

Schwartz et al in a study of 26 meningiomas confirmed the presence both of oestrogen receptor and progesterone receptor, but because of an apparent lack of steroid binding specificity concluded that the receptor proteins found in meningiomas were unlikely to be specific steroid receptors. ${ }^{24}$ The results of this and numerous other studies, however, seem to indicate otherwise. It is unlikely that the progesterone receptor activity in our study represents non-specific binding of radioligand to low affinity molecules. Isoelectric focusing is a technique that is eminently suitable for separating receptor bound radioligands from those that are non-specifically bound, especially when working with small volumes as in the technique used in this study. ${ }^{39}$ The isoelectric focusing profile of progesterone receptor in meningiomas was identical to that obtained in control tissues, and similar results have been obtained from human breast carcinomas. ${ }^{33}$ Furthermore, the competitive inhibition studies showed the highly specific nature of the cytosolic progesterone receptor in meningiomas. Similar results were obtained by other authors, ${ }^{1520}$ and Scatchard plot analysis both in this and other reports has further established the high affinity nature of cytosolic progesterone receptor in meningiomas. ${ }^{151920}$

An analysis of the clinical features of patients whose tumours were studied in this series confirms previous reports that there is no correlation between the presence of progesterone receptor and the age, sex, or menopausal state in the patients studied, or the site of the neoplasm. In the patients with multiple neoplasms it was interesting to note that no generalised predictions could be made regarding the steroid hormone receptor state of the tumours removed. One of the female patients in this series had a familial history of neurofibromatosis with predominantly central manifestations, details of which are published elsewhere. ${ }^{41}$ The presence of progesterone receptor in patients with multiple, recurrent, or extensively infiltrative neoplasms is of particular interest as it raises the possibility of hormonal manipulation as a form of treatment in adjunct to surgery. This possibility merits investigations in vitro before clinical trials are started.

The presence of cytosolic progesterone receptor in meningiomas in the apparent absence of oestrogen receptor has led to speculation that, in contrast to other cells, the synthesis of progesterone receptor in meningiomas may not be modulated by oestrogens acting through oestrogen receptor. ${ }^{25}$ Alternatively, it has been suggested that meningiomas containing clinically important quantities of cytosolic progesterone receptor may also contain nuclear oestrogen receptor occupied by endogenous oestrogens which cannot be readily detected by current assay techniques. ${ }^{42}$ The presence of nuclear oestrogen and progesterone receptor in meningiomas has been reported, ${ }^{26}$ but the relation of such receptors to free cytosolic receptors remains unclear. Further studies on the presence of nuclear receptors in meningiomas are required before accepting the presence of an oestrogen independent progesterone receptor in these neoplasms. The use of other techniques - for example, cellular localisation of oestrogen receptor using monoclonal antibodies -43 may be of considerable value.

We thank Mr A Buxton and Mr D Brocklehurst for technical help and Mrs P Kirk for typing the manuscript. Financial support from the Trent Regional Health Authority locally organised NHS research 
fund (account number 050) and the Yorkshire Cancer Research Campaign is gratefully acknowledged.

\section{References}

${ }^{1}$ Russell DS, Rubinstein LJ. Pathology of tumours of the nervous system. 4th ed. London: Edward Arnold, 1977:65-100.

${ }^{2}$ Cushing H, Eisenhardt L. Meningiomas: their classification, regional behaviour, life history and surgical end results. Springfield, Illinois: Thomas CC, 1938.

${ }^{3}$ Michelson JJ, New PFJ. Brain tumour and pregnancy. J Neurol Neurosurg Psychiatry 1969;32:305-7.

${ }^{4}$ Bickerstaff ER, Small JM, Guest IA. The relapsing cause of certain meningiomas in relation to pregnancy and menstruation. $J \mathrm{Neu}$ rol Neurosurg Psychiatry 1958;32:89-91.

${ }^{5}$ Schoenberg BS, Christine BW, Whisnaut NP. Nervous system neoplasms and primary malignancies of other sites. The unique association between meningiomas and breast cancer. Neurology 1975;26:705-12.

${ }^{6}$ McGuire WL, Horowitz KB, Pearson OH, Segaloff A. Current status of estrogen and progesterone receptors in breast cancer. Cancer 1977;39:2934-47.

${ }^{7}$ Poisson M, Magdelenat H, Martin PM, et al. Récepteurs de la progestérone de la leptoméninge humaine normale chez l'adulte. Rev Neurol 1984;140:14-19.

${ }^{8}$ Donnell BA, Meyer GA, Donegan WL. Estrogen-receptor protein in intracranial meningiomas. $J$ Neurosurg 1979;50:499-502.

${ }^{9}$ Poisson M, Magdelenat H, Foncin JF, et al. Recepteurs d'oestrogènes et de progestérone dans les méningiomes. Rev Neurol 1980;136:193-203.

${ }^{10}$ Martuza RL, MacLaughlin DT, Ojemann RG. Specific estradiol binding in schwannomas, meningiomas and neurofibromas. Neurosurg 1981;9:665-71.

${ }^{11}$ Schnegg J-F, Gomez F, Le Marchand-Beraud T, de Tribolet N. Presence of sex steroid hormone receptors in meningioma tissue. Surg Neurol 1981;15:415-18.

${ }^{12}$ Magdelenat H, Pertuiser BF, Poisson M, et al. Progestin and oestrogen receptors in meningiomas. Biochemical characterisation, clinical and pathological correlatons in 42 cases. Acta Neurochir 1982;64:199-213.

${ }^{13}$ Tilzer LL, Plapp FV, Evans JP, Stone D, Alward K. Steroid receptor proteins in human meningiomas. Cancer 1982;49:633-36.

${ }^{14}$ Yu Z-Z, Wrange O, Haglund B, Granholm L, Gustafsson J-A. Estrogen and progestin receptors in intracranial meningiomas. $J$ Steroid Biochem 1982;16:451-56.

15 Blankenstein MA, Blaauw G, Lamberts SWJ, Mulder E. Presence of progesterone receptors and absence of oestrogen receptors in human intracranial meningioma cytosis. Eur $J$ Cancer Clin Oncol 1983;19:365-70.

${ }^{16}$ Glick RP, Molteni A, Fors EM. Hormone binding in brain tumours. Neurosurg 1983;13:513-19.

${ }^{17}$ Hinton D, Mobbs EG, Sima AA, Hanna W. Steroid receptors in meningiomas. A histochemical and biochemical study. Acta Neuropathol 1983;62:134-40.

${ }^{18}$ Vaquero J, Marcos ML, Martinez R, Bravo G. Estrogen- and progesterone-receptor proteins in intracranial receptors. Surg Neurol 1983;19:11-13.

${ }^{19}$ Markwalder T-M, Zava DT, Goldhirsch A, Markwalder RV. Estrogen and progesterone receptors in meningiomas in relation to clinical and pathological features. Surg Neurol 1983;20:42-7.

${ }^{20}$ Poisson P, Pertuiset BF, Hauw J-J, et al. Steroid hormone receptors in human meningiomas, gliomas and brain metastases. $J$ Neurooncol 1983;1:179-89.

${ }^{21}$ Cahill DW, Bashirelahi N, Soloman LW, Dalton T, Salcman M, Ducker TB. Estrogen and progesterone receptors in meningiomas. J Neurosurg 1984;60:985-93.

${ }^{22}$ Concolino G, Guiffre R, Margiotto G, Liccardo G, Marocchi A. Steroid receptors in CNS: estradiol (ER) and progesterone (PR) receptors in human spinal cord tumors. J Steroid Biochem 1984;20:491-4.

${ }^{23}$ Poisson M, Pertuiset BF, Moguileusky M, Magdelenat H, Martin PM. Les récepteurs de stéroides du système nerveux central. Implications en neurologie. Rev Neurol 1984;140:233-48.

${ }^{24}$ Schwartz MR, Randolph RL, Cech DA, Rose JE, Panko WB. Steroid hormone receptors in meningiomas. Failure to meet criteria of specific receptors. Cancer 1984;53:922-7.

${ }^{25}$ Whittle IR, Foo MS, Besser M, Vanderfield GK. Progesterone and oestrogen receptors in meningiomas: biochemical and clinicopathological considerations. Aust NZ J Surg 1984;54:325-30.

${ }^{26}$ Martuza RL, Miller DC, MacLaughlin DT. Estrogen and progestin binding by cytosolic and nuclear fractions of human meningiomas. $J$ Neurosurg 1985;62:750-6.

${ }^{27}$ Jones GRN. Losses of nitrogenous material occurring from frozen sections of rat liver during incubation in an aqueous medium. Biochem J 1965;96:10P.

${ }^{28}$ Penney GC, Hawkins RA. Histochemical detection of oestrogen receptors: a progress report. Br J Cancer 1982;45:237-46.

${ }^{29}$ Underwood JCE, Sher E, Reed M, Eisman JA, Martin TJ. Biochemical assessment of histological methods for oestrogen receptor localisation. J Clin Pathol 1982;35:401-6.

${ }^{30}$ Underwood JCE, Dangerfield VJM, Parsons MA. Oestrogen receptor assay of cryostat sections of human breast carcinomas with simultaneous quantitative histology. J Clin Pathol 1983;36:399-405.

${ }^{31}$ Hartree EF. Determination of protein: a modification of the Lowry method that gives a linear photometric response. Anal Biochem 1972;48:422-27.

${ }^{32}$ Scatchard G. The attractions of proteins for small molecules and ions. Ann NYAcad Sci 1949;51:660-72.

${ }^{33}$ Jänne $\mathbf{O}$, Kontula K, Vihko R. Progestin receptors in human tissues: concentrations and binding kinetics. J Steroid Biochem 1976;7:1061-8.

${ }^{34}$ Zülch KJ. Histological typing of tumours of the central nervous system. Geneva: World Health Organisation, 1979:53-6.

${ }^{35}$ Raynaud JP, Ojasoo T, Delarue JC, et al. Estrogen and progestin receptors in human breast cancer. In: McGuire WL, Raynaud JP, Baulieu EE, eds. Progesterone receptors in normal and neoplastic tissues. New York: Raven Press, 1977:171-91.

${ }^{36}$ Fleischmann G, Beato M. Characterisation of the progesterone receptor of rabbit uterus with the synthetic progestin 16 alphaethyl-21-hydroxy-19-norpregn-4-ene-3,20 dione. Biochim et Biophys Acta 1978;540:500-17.

${ }^{37}$ Isomaa V. In vitro binding to and in vivo effect on the cytosol and nuclear receptors of various progestins, and their relationship to synthesis of uteroglobulin in rabbit uterus. Biochem et Biophys Acta 1981;675:9-16.

${ }^{38}$ Koenders AJM, Geurts-Moespot J, Beex LVAM, Benraad ThJ. Assay of progesterone receptor binding sites with 17,21-dimethyl-19-norpregna-4,9-diene-3,20 dione and 16 alpha-ethyl-21-hydroxy-19-nor-4-pregene-3,20 dione as the radioactive ligands. $J$ Endocrinol 1979;80:15.

${ }^{39}$ Gustafsson J-A, Gustafsson SA, Nordenskjöld B, Okret S, Silfverswärd C, Örjan W. Estradiol receptor analysis in human breast cancer tissue by isoelectric focusing in polyacrylamide gel. Cancer Res 1978;38:4225-8.

${ }^{40}$ Wrange $\varnothing$, Humla S, Ramberg I, et al. Progestin-receptor analysis in human breast cancer cytosol by isoelectric focusing in slabs of polyacrylamide gel. J Steroid Biochem 1981;14:141-8.

${ }^{41}$ Battersby RDE, Ironside JW, Maltby EL. Inherited multiple meningiomas: a clinical, pathological and cytogenetic study of an affected family. $J$ Neurol Neurosurg Psychiatry in press.

${ }^{42}$ Cahill DW. Reply to letter. J Neurosurg 1985;62:162-3.

${ }^{43} \mathrm{King}$ WJ, Greene GL. Monoclonal antibodies localize oestrogen receptor in the nuclei of target cells. Nature 1984;307:745-7.

Request for reprints to: Dr JW Ironside, Department of Neuropathology, Royal Hallamshire Hospital, Sheffield S10 2JF, England. 